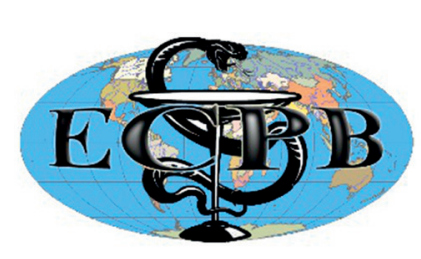

“ЕКСПЕРИМЕНТАЛЬНА ТА КЛІНІЧНА ФІЗІОЛОГІЯ І БІОХІМІЯ” "EXPERIMENTAL AND CLINICAL PHYSIOLOGY AND BIOCHEMISTRY" Науково-практичний журнал/Scientific-practical journal

Наукові статті / Research article ECPB 2019, 1(85): 10-17. https://doi.org/

\title{
Features of Endocrine and Immune Status in Rats with Different State of Autonomous Nervous System
}

\author{
O.I. MELNYK ${ }^{1}$, O.G. MYSAKOVETS ${ }^{1}$, I.L. POPOVYCH ${ }^{2,3}$ \\ ${ }^{1}$ Danylo Halytskyi National Medical University, Lviv, Ukraine \\ ${ }^{2} \mathrm{OO}$ Bohomolets Institute of Physiology, Kyiv, Ukraine \\ ${ }^{3}$ Ukrainian Scientific Research Institute of Medicine for Transport, Odesa, Ukraine \\ E-mail:oksana@meduniv.lviv.ua; i.popovych@biph.kiev.ua
}

The presence of interconnections between the parameters of the nervous, endocrine and immune systems within the framework of the triple complex is well known $[5,6,9,18,20]$. However, data on the nature (synergism or antagonism) of the influence of the sympathetic and vagus link of the autonomic nervous system on the individual parameters of immunity are ambiguous [11-15,21,24-26]. Consequently, research in this area remains relevant. One of the approaches to solving this problem is to compare immunity parameters in individuals with different states of the autonomic nervous system, both constitutional and induced vegetotropic factors. This is what determined the purpose of this study.

Material and methods. The experiment is at 60 female and 50 male white rats Wistar line weighing 210-320 g. Of these for 10 animals of each sex not subjected to any influences and others within 6-7 days were subjected to different manipulations (fixation in the hand of the experimenter, infusion into the stomach through a probe of various liquids, application of ozokerite to the tail with 30 -minute immobilization).

The day after the completion of stressing or adaptogenic manipulations in all rats took samples of peripheral blood (through a cut tail) to analyze of leukocytogram. An hour under light ether anesthesia for 15-20 sec recorded ECG in standard lead II (introducing needle electrodes subcutaneously) to determine parameters of heart rate variability (HRV) [1]. The next day, the animals were decapitated, for the purpose of collecting blood. The plasma levels of the hormones of adaptation were determined: corticosterone, triiodothyronine, thyroxine and testosterone (by the ELISA); as well as electrolytes: calcium (by reaction with arsenase III), phosphates (phosphate-molybdate method), sodium and potassium (by flamming photometry).

According to the plasma level of electrolytes hormonal activity was evaluated: parathyrin by coefficient $(\mathrm{Cap} / \mathrm{Pp})^{0,5}$, calcitonin by coefficient $(\mathrm{Cap} \cdot \mathrm{Pp})^{-0,5}$ and mineralocorticoid by coefficient $(\mathrm{Nap} / \mathrm{Kp})^{0,5}$, based on their classical effects and recommendations by IL Popovych [21].

The analyzes were carried out according to the instructions described in the manual [4,7]. The analyzers "Tecan" (Oesterreich), "Pointe-180" ("Scientific", USA) and "Reflotron" (Boehringer Mannheim, BRD) were used with appropriate sets and a flamming spectrophotometer "CФ-47". 
Immunological parameters were determined by tests as described in the handbook [16] and the previously developed algorithm [3]. On the state of the phagocytic function of neutrophils (microphages) and monocytes (macrophages) judged by phagocytic index, microbial (phagocytic) number and index of killing regarding museum culture Staphylococcus aureus (ATCC N 25423 F49) [3], with the calculation of bactericidal capacity (number of microbes that are able to neutralize neutrophils or monocytes contained in $1 \mathrm{~L}$ of blood) [21].

Among the parameters of immunogram determined the relative amount of blood population of T-cells by spontaneous rosette test with sheep erythrocytes by $\mathrm{M}$ Jondal et al [8], their theophylline resistant (T-helper) and theophylline sensitive (T-cytotoxic) subpopulations (by test sensitivity rosette to theophylline by S Limatibul et al [17]), the population of B-lymphocytes by test complementary rosette of sheep erythrocytes by C Bianco [2]. Natural killers identified as big containing granules lymphocytes.

After a blood sample was removed spleen, thymus and adrenal glands and weighed them. From the spleen and thymus did smears for counting splenocytogram and thymocytogram [3]. For the latter, as well as immunocytogram and leukocytogram we calculated entropy $[21,25]$. In addition, the modules of deviation from the norm of monocytes, eosinophils and stubnucleary neutrophils of the leukocytogram were calculated, on the basis of which its disharmony was calculated [15].

In sections of the adrenal glands was measured under a microscope the thickness of glomerular, fascicular, reticular and medullar zones [3].

Digital material it is traited using the package of softwares "Statistica 5.5".

Results and discussion. The sympathetic tone estimated by AMo in intact males is (Mean $\pm \mathrm{SD}$ ) $53 \pm 24 \%$, in females $56 \pm 17 \%$, and the vagus tone, estimated at MxDMn, is $45 \pm 25 \mathrm{msec}$ vs $53 \pm 41 \mathrm{msec}$, respectively, that is, almost the same. Instead, the value of Moda as a marker of the humoral regulation channel was significantly higher in males: $189 \pm 36 \mathrm{msec}$ vs $124 \pm 16 \mathrm{msec}$, respectively $(p<0,001)$. The integral state of the autonomic nervous system is usually judged by the Baevsky Stress-index (SI). IL Popovych modified the formula to a more adequate form: $\mathrm{SI}=(\mathrm{AMo} / 2 \cdot \mathrm{Mo} \cdot \mathrm{MxDMn})^{1 / 3}[19,26]$. The magnitude of the Stress-index was slightly higher in females: 0,165 $\pm 0,077$ units vs $0,190 \pm 0,074$ units $(p>0,5)$. Previously, we found sexual dimorphism of a number of parameters of the neuroendocrine-immune complex both in rats [22] and in humans [23]. Therefore, for the correct comparison, the actual values of the variables (V) were listed in Z-scores according to the classical formula: $\mathrm{Z}=(\mathrm{V} / \mathrm{I}-1) / \mathrm{Cv}$, where $\mathrm{I}$ is the average value for intact males or females, $\mathrm{Cv}$ are coefficients of variation.

At the next stage, three groups were formed according to the integral state of the autonomic nervous system. If we accept the range: $-0,5 \mathrm{Z} \div+0,5 \mathrm{Z}$ as the eutonia, then it is confirmed in 25 rats (14 males and 11 females). In 33 rats (12 males and 21 females), vagotonia was confirmed, whereas in 52 rats (24 males and 28 females), sympathicotonia was observed. Such a spectrum is due, obviously, to the stressful influence of the applied factors [15,21].

In order to detect endocrine and immune parameters, the totality of which three states of autonomous regulation differ significantly, a discriminant analysis was carried out using the forward stepwise method [10]. The program is included in the model 17 parameters. In particular, in addition to the three HRV parameters, by definition, three endocrine parameters, two parameters of thymocytogram, five parameters of splenocytogram and three immune parameters of blood appeared to be characteristic. In addition, worth noting yet another 16 parameters that were out of the model (Tables 1 and 2). 
Table 1

Discriminant Function Analysis Summary Step 17, N of vars in model: 17; Grouping: 3 grps Wilks' Lambda: 0,0833; approx. $\mathrm{F}_{(34)}=13 ; \mathrm{p}<10^{-4}$

\begin{tabular}{|c|c|c|c|c|c|c|c|c|}
\hline \begin{tabular}{|c|}
$\begin{array}{c}\text { Variables currently } \\
\text { in the model }\end{array}$ \\
\end{tabular} & $\begin{array}{c}\text { Vagotonia } \\
\quad(33)\end{array}$ & $\begin{array}{c}\text { Eutonia } \\
(25)\end{array}$ & \begin{tabular}{|l|}
$\begin{array}{l}\text { Sympathico- } \\
\text { tonia (52) }\end{array}$ \\
\end{tabular} & \begin{tabular}{|c|} 
Wilks' \\
$\Lambda$
\end{tabular} & \begin{tabular}{|l|} 
Parti- \\
al $\Lambda$ \\
\end{tabular} & $\begin{array}{l}\text { F-re- } \\
\text { move }\end{array}$ & \begin{tabular}{|c|} 
p-le- \\
vel
\end{tabular} & \begin{tabular}{|l|} 
Tole- \\
rancy
\end{tabular} \\
\hline \begin{tabular}{|c|}
$\begin{array}{c}\text { MxDMn as Vagal } \\
\text { tone }\end{array}$ \\
\end{tabular} & $+1,05 \pm 0,13$ & $-0,23 \pm 0,07$ & $-1,12 \pm 0,04$ & ,114 & ,729 & 16,9 & $10^{-6}$ & ,569 \\
\hline \begin{tabular}{|c|}
$\begin{array}{c}\text { Moda as Humoral } \\
\text { channel }\end{array}$ \\
\end{tabular} & $+0,93 \pm 0,10$ & $-0,33 \pm 0,11$ & $-1,48 \pm 0,10$ & , 103 & ,813 & 10,5 & $10^{-4}$ & ,338 \\
\hline $\begin{array}{c}\text { Eosinophils of } \\
\text { Blood }\end{array}$ & $+0,23 \pm 0,18$ & $+0,04 \pm 0,21$ & $-0,35 \pm 0,12$ & 099 & ,842 & 8,5 & $10^{-3}$ & ,339 \\
\hline \begin{tabular}{|c|}
$\begin{array}{c}\text { Lymphoblastes of } \\
\text { Spleen }\end{array}$ \\
\end{tabular} & $+0,23 \pm 0,20$ & $-0,01 \pm 0,23$ & $-0,36 \pm 0,12$ & ,089 & ,942 & 2,8 &, 065 & ,610 \\
\hline $\begin{array}{c}\text { Lymphoblastes of } \\
\text { Thymus }\end{array}$ & $+0,08 \pm 0,24$ & $-0,08 \pm 0,20$ & $-0,56 \pm 0,18$ & 088 & ,951 & 2,3 &, 103 & ,850 \\
\hline $\begin{array}{c}\text { Plasmocytes of } \\
\text { Spleen }\end{array}$ & $+0,13 \pm 0,19$ & $-0,15 \pm 0,17$ & $-0,28 \pm 0,12$ & ,085 & ,978 & 1,0 & , 358 & ,706 \\
\hline $\begin{array}{c}\text { Lymphocytes of } \\
\text { Spleen }\end{array}$ & $+0,06 \pm 0,16$ & $-0,10 \pm 0,17$ & $-0,33 \pm 0,16$ & 091 & ,914 & 4,3 &, 017 & ,496 \\
\hline $\begin{array}{c}\text { AMo as Sympa- } \\
\text { thetic tone }\end{array}$ & $-0,86 \pm 0,12$ & $-0,07 \pm 0,11$ & $+1,32 \pm 0,10$ & , 100 & ,834 & 9,0 & $10^{-3}$ & ,408 \\
\hline Corticosterone & $-0,47 \pm 0,17$ & $+0,13 \pm 0,21$ & $+0,53 \pm 0,20$ & 086 & ,964 & 1,7 &, 189 & ,669 \\
\hline $\begin{array}{l}\text { Entropy of Thy- } \\
\text { mocytogram }\end{array}$ & $-0,06 \pm 0,23$ & $+0,28 \pm 0,20$ & $+0,56 \pm 0,14$ & ,085 & ,978 & 1,0 & , 369 & ,776 \\
\hline $\begin{array}{c}(\mathrm{Na} / \mathrm{K})^{0,5} \text { of } \\
\text { Plasma }\end{array}$ & $+0,59 \pm 0,26$ & $-0,17 \pm 0,14$ & $+0,51 \pm 0,15$ & ,088 & ,943 & 2,8 &, 069 & ,806 \\
\hline \begin{tabular}{|c|}
$\begin{array}{c}\text { Natural Killers of } \\
\text { Blood }\end{array}$ \\
\end{tabular} & $+0,36 \pm 0,34$ & $-0,19 \pm 0,26$ & $+0,28 \pm 0,22$ & ,088 & ,946 & 2,6 & ,081 & ,641 \\
\hline $\begin{array}{c}\text { Entropy of Leu- } \\
\text { kocytogram }\end{array}$ & $+0,04 \pm 0,19$ & $-0,41 \pm 0,27$ & $-0,08 \pm 0,18$ & ,086 & ,969 & 1,5 & ,234 &, 547 \\
\hline $\begin{array}{l}\text { Fibroblastes of } \\
\text { Spleen }\end{array}$ & $-0,14 \pm 0,18$ & $+0,31 \pm 0,27$ & $-0,05 \pm 0,14$ & 091 & ,915 & 4,2 &, 018 &, 492 \\
\hline Thyroxine & $-0,18 \pm 0,14$ & $+0,14 \pm 0,21$ & $-0,13 \pm 0,12$ & 087 & ,961 & 1,8 &, 164 & ,658 \\
\hline $\begin{array}{c}\text { Eosinophils of } \\
\text { Spleen }\end{array}$ & $+0,18 \pm 0,17$ & $+0,41 \pm 0,26$ & $+0,02 \pm 0,13$ &, 086 & ,966 & 1,6 &, 205 &, 717 \\
\hline \begin{tabular}{|c|}
$\begin{array}{c}\text { Blood Monocytes } \\
\text { Deviation }\end{array}$ \\
\end{tabular} & $+0,31 \pm 0,11$ & $+0,53 \pm 0,13$ & $+0,43 \pm 0,09$ & ,089 & ,936 & 3,1 &, 049 & ,813 \\
\hline \begin{tabular}{|c|}
$\begin{array}{c}\text { Variables cur- } \\
\text { rently not in the } \\
\text { model }\end{array}$ \\
\end{tabular} & $\begin{array}{l}\text { Vagotonia } \\
\quad(33)\end{array}$ & $\begin{array}{l}\text { Eutonia } \\
\quad(25)\end{array}$ & $\begin{array}{c}\text { Sym- } \\
\text { pathicotonia } \\
(52)\end{array}$ & $\begin{array}{c}\text { Wilks' } \\
\Lambda\end{array}$ & $\begin{array}{c}\text { Par- } \\
\text { ti- } \\
\text { al } \Lambda\end{array}$ & $\begin{array}{l}\mathrm{F} \text { to } \\
\text { en- } \\
\text { ter }\end{array}$ & $\begin{array}{c}\text { p-le- } \\
\text { vel }\end{array}$ & $\begin{array}{c}\text { Tole- } \\
\text { ran- } \\
\text { cy }\end{array}$ \\
\hline $\begin{array}{l}\text { Macrophages of } \\
\text { Spleen }\end{array}$ & $-0,41 \pm 0,14$ & $+0,28 \pm 0,16$ & $+1,14 \pm 0,13$ & ,083 & ,996 & , 18 &, 839 & ,381 \\
\hline $\begin{array}{c}(\mathrm{Ca} \cdot \mathrm{P})^{-0,5} \text { of } \\
\text { Plasma }\end{array}$ & $-0,18 \pm 0,09$ & $-0,09 \pm 0,10$ & $0,00 \pm 0,08$ & ,082 & ,989 &, 52 &, 596 & ,859 \\
\hline $\begin{array}{c}\text { Macrophages of } \\
\text { Thymus }\end{array}$ & $+0,37 \pm 0,23$ & $+1,02 \pm 0,31$ & $+1,17 \pm 0,33$ & ,083 & 1,000 &, 01 & ,991 & ,634 \\
\hline Testosterone & $+0,05 \pm 0,26$ & $+0,63 \pm 0,23$ & $+0,74 \pm 0,26$ & ,082 &, 984 &, 75 &, 475 &, 870 \\
\hline $\begin{array}{l}\text { Adrenals Mass } \\
\text { Index } \\
\end{array}$ & $+0,45 \pm 0,24$ & $0,00 \pm 0,42$ & $-0,24 \pm 0,20$ & 083 & ,991 & ,39 &, 675 &, 924 \\
\hline
\end{tabular}




\begin{tabular}{|c|c|c|c|c|c|c|c|c|}
\hline $\begin{array}{c}\text { Killing Index of } \\
\text { Neutrophils }\end{array}$ & $+0,48 \pm 0,20$ & $+0,21 \pm 0,22$ & $+0,15 \pm 0,15$ &, 083 &, 994 &, 28 &, 760 &, 731 \\
\hline $\begin{array}{c}\text { Spleen Mass } \\
\text { Index }\end{array}$ & $+0,10 \pm 0,14$ & $-0,05 \pm 0,19$ & $-0,19 \pm 0,11$ &, 083 &, 992 &, 36 &, 697 &, 714 \\
\hline $\begin{array}{c}\text { Leukocytogram } \\
\text { Disharmony }\end{array}$ & $+0,39 \pm 0,06$ & $\mathbf{+ 0 , 7 0} \pm \mathbf{0 , 1 3}$ & $+0,53 \pm 0,07$ &, 083 &, 998 &, 07 &, 933 &, 630 \\
\hline $\begin{array}{c}\text { Stub Neutrophils } \\
\text { Deviation }\end{array}$ & $+0,48 \pm 0,14$ & $\mathbf{+ 1 , 0 3} \pm \mathbf{0 , 2 8}$ & $+0,69 \pm 0,16$ &, 083 &, 994 &, 27 &, 763 &, 759 \\
\hline $\begin{array}{c}\text { Stub Neutrophils } \\
\text { of Blood }\end{array}$ & $-0,22 \pm 0,19$ & $\mathbf{- 0 , 7 7} \pm \mathbf{0 , 3 3}$ & $-0,08 \pm 0,21$ &, 082 &, 985 &, 68 &, 510 &, 450 \\
\hline $\begin{array}{c}\text { Neutrophils of } \\
\text { Spleen }\end{array}$ & $+0,23 \pm 0,25$ & $\mathbf{- 0 , 5 1} \pm \mathbf{0 , 2 7}$ & $-0,33 \pm 0,21$ &, 082 &, 980 &, 92 &, 403 &, 575 \\
\hline $\begin{array}{c}\text { Plasmocytes of } \\
\text { Blood }\end{array}$ & $+0,18 \pm 0,21$ & $\mathbf{+ 0 , 2 2 \pm 0 , 2 3}$ & $\mathbf{+ 0 , 6 2} \pm \mathbf{0 , 2 0}$ &, 083 &, 994 &, 25 &, 778 &, 602 \\
\hline Thymus Mass & $+0,12 \pm 0,18$ & $+0,22 \pm 0,22$ & $\mathbf{+ 0 , 4 3} \pm \mathbf{0 , 1 4}$ &, 082 &, 982 &, 84 &, 435 &, 807 \\
\hline $\begin{array}{c}\text { Hassal corpuscles } \\
\text { of Thymus }\end{array}$ & $+0,05 \pm 0,17$ & $+0,42 \pm 0,17$ & $\mathbf{+ 0 , 4 6} \pm \mathbf{0 , 1 3}$ &, 083 &, 993 &, 30 &, 742 &, 437 \\
\hline $\begin{array}{c}\text { Lymphocytes of } \\
\text { Thymus }\end{array}$ & $-0,13 \pm 0,20$ & $-0,12 \pm 0,24$ & $\mathbf{- 0 , 6 9} \pm \mathbf{0 , 1 7}$ &, 083 &, 991 &, 41 &, 662 &, 448 \\
\hline $\begin{array}{c}\text { Epitheliocytes of } \\
\text { Thymus }\end{array}$ & $+0,11 \pm 0,21$ & $+0,01 \pm 0,24$ & $\mathbf{+ 0 , 4 6} \pm \mathbf{0 , 1 2}$ &, 083 & 1,000 &, 01 &, 992 &, 667 \\
\hline
\end{tabular}

Summary of Stepwise Analysis

Table 2

\begin{tabular}{|c|c|c|c|c|c|}
\hline MxDMn as Vagal tone & F to enter & $\mathrm{p}$-level & $\Lambda$ & F-value & p-level \\
\hline AMo as Sympathetic tone & 214 & $10^{-6}$ &, 200 & 213,8 & 0,00 \\
\hline Moda as Humoral channel & 11,8 & $10^{-4}$ &, 164 & 78,0 & 0,00 \\
\hline Eosinophils of Blood & 4,7 &, 011 &, 150 & 55,3 & 0,00 \\
\hline Blood Monocytes Deviation & 3,5 &, 034 &, 141 & 43,3 & 0,00 \\
\hline Plasmocytes of Spleen & 3,6 &, 030 &, 131 & 36,2 & 0,00 \\
\hline (Na/K) $^{0,5}$ of Plasma & 2,9 &, 059 &, 124 & 31,2 & 0,00 \\
\hline Corticosterone & 2,5 &, 089 &, 119 & 27,5 & 0,00 \\
\hline Thyroxine & 2,5 &, 084 &, 113 & 24,7 & 0,00 \\
\hline Entropy of Leukocytogram & 1,8 &, 165 &, 109 & 22,3 & 0,00 \\
\hline Lymphoblastes of Thymus & 1,9 &, 157 &, 105 & 20,5 & 0,00 \\
\hline Natural Killers of Blood & 1,5 &, 226 &, 102 & 18,8 & 0,00 \\
\hline Lymphocytes of Spleen & 1,3 &, 272 &, 099 & 17,4 & 0,00 \\
\hline Fibroblastes of Spleen & 2,2 &, 121 &, 095 & 16,5 & 0,00 \\
\hline Lymphoblastes of Spleen & 1,9 &, 152 &, 091 & 15,6 & 0,00 \\
\hline Eosinophils of Spleen & 1,6 &, 217 &, 088 & 14,7 & 0,00 \\
\hline Entropy of Thymocytogram & 1,5 &, 231 &, 085 & 14,0 & 0,00 \\
\hline Entropy of Thymocytogram & 1,0 &, 369 &, 083 & 13,2 & 0,00 \\
\hline
\end{tabular}

Recognition information contained in the listed variables is condensed in two discriminant roots, $92,7 \%$ in the first and 7,38 \% in the second. Calculating the values of individual roots by adding products of discriminant variables to their Raw Coefficients plus the Constant (Table 3) makes it possible to visualize each rat in a two-dimensional information space of radicals (Fig. 1). 
Standardized, Structural and Raw Coefficients and Constants for Discriminant Variables

\begin{tabular}{|c|c|c|c|c|c|c|}
\hline Coefficients & \multicolumn{2}{|c|}{ Standardized } & \multicolumn{2}{|c|}{ Structural } & \multicolumn{2}{|c|}{ Raw } \\
\hline Variables currently in the model & Root 1 & Root 2 & Root 1 & Root 2 & Root 1 & Root 2 \\
\hline MxDMn as Vagal tone &,- 696 & ,395 &,- 765 & ,041 & $-1,480$ & 839 \\
\hline Moda as Humoral channel &,- 628 & ,775 &,- 629 &,- 110 &,- 984 & 1,215 \\
\hline Eosinophils of Blood & ,241 & $-1,092$ &,- 102 &,- 086 & ,256 & $-1,156$ \\
\hline Lymphoblastes of Spleen & 040 &,- 521 &,- 096 &,- 058 & 039 &,- 510 \\
\hline Lymphoblastes of Thymus &,- 212 &,- 229 &,- 084 &,- 090 &,- 167 &,- 181 \\
\hline Plasmocytes of Spleen &,- 170 & ,136 &,- 073 & 026 &,- 182 & 147 \\
\hline Lymphocytes of Spleen & ,315 &,- 500 &,- 065 &,- 037 & 314 &,- 497 \\
\hline AMo as Sympathetic tone &, 108 & 1,067 &, 541 & ,394 & 160 & 1,573 \\
\hline Corticosterone &, 128 & ,337 &, 128 &,- 010 & 104 & ,275 \\
\hline Entropy of Thymocytogram & 073 &,- 258 & ,093 &, 005 & 066 &,- 234 \\
\hline$(\mathrm{Na} / \mathrm{K})^{0,5}$ of Plasma &,- 074 & ,436 &,- 008 & ,360 &,- 064 &, 377 \\
\hline Natural Killers of Blood & ,293 &,- 160 &,- 006 &, 173 &, 179 &,- 097 \\
\hline Entropy of Leukocytogram & 013 & ,405 &,- 013 &, 172 & 010 & ,329 \\
\hline Fibroblastes of Spleen & 090 &,- 689 & 011 &,- 205 & 081 &,- 619 \\
\hline Thyroxine &, 135 &,- 353 &, 007 &,- 188 &, 150 &,- 391 \\
\hline Eosinophils of Spleen &, 014 &,- 370 &,- 028 &,- 181 &, 014 &,- 356 \\
\hline Blood Monocytes Deviation &, 296 &,- 087 &, 030 &,- 142 & ,469 &,- 138 \\
\hline Eigenvalues & 6,822 &, 534 & \multicolumn{2}{|c|}{ Constants } & $-1,158$ &, 043 \\
\hline Discriminant Properties, \% & 92,7 & 7,3 & & & & \\
\hline Canonical R & ,934 &, 590 & & & & \\
\hline Wilks' Lambda & ,083 & ,652 & & & & \\
\hline Chi-Sqr. & 246 & 42 & & & & \\
\hline Degree freedom & 34 & 16 & & & & \\
\hline p-level & $10-6$ & ,0003 & & & & \\
\hline
\end{tabular}

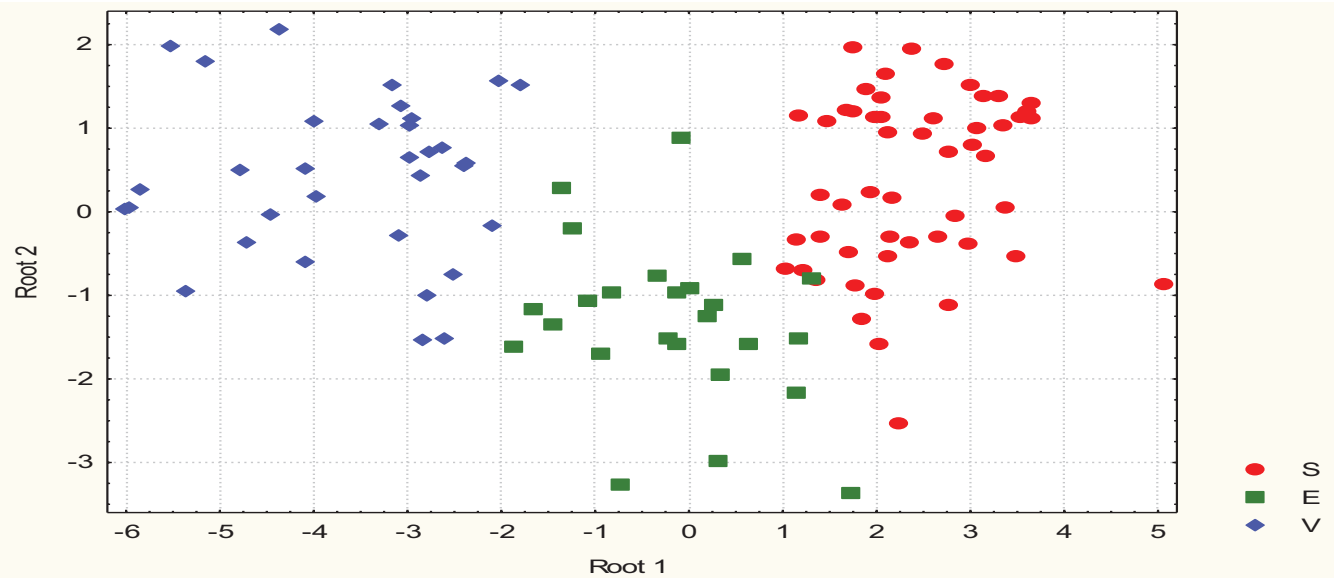

Fig. 1. Individual Roots values for rats in state of vagotonia (V), eutonia (E) and sympathicotonia (S) 
Even at first glance it is possible to state a clear enough difference between clusters. The visual impression is documented by calculating the square of Mahalanobis distance $\left(\mathrm{D}^{2}{ }_{\mathrm{M}}\right)$. Between eutonic and sympathicotonic rats $\mathrm{D}^{2}{ }_{\mathrm{M}}=10$ $\left(\mathrm{F}=7,9 ; p<10^{-6}\right)$, between eutonic and vagotonic rats: $15\left(\mathrm{~F}=10,6 ; p<10^{-6}\right)$, while between sympathicotonic and vagotonic rats distance is drastical: 37 $\left(\mathrm{F}=36,5 ; p<10^{-6}\right)$.

Extreme left localization vagotonic rats cluster along the axis of the first root (cluster centroid: $-3,62$ ) reflect their minimal among cohort size positively correlating with the root not only the Sympathetic tone, but also plasma level of Corticosterone and Entropy of Thymocytogram, while the maximum value negatively correlating with the root not only the Vagal tone and Moda (minimal Heart Rate), but also blood level of Eosinophils as well as level of Lymphoblastes in Thymus and Lymphoblastes, Plasmocytes and Lymphocytes in Spleen (Table 3). Instead, the sympathicotonic rats occupy the rightmost zone of the axis of the first root (centroid: $+2,38$ ), which reflects the opposite deviations of the listed parameters. The intermediate position is occupied by eutonic rats (centroid: -0,18).

Instead, along the axis of the second root eutonic rats occupy the extreme lower zone (centroid: -1,33) that reflects their minimum value among a cohort of Mineralocorticoid Activity, blood level of Natural Killers and Entropy of Leukocytogram which associated with the root directly, while the maximum value inverted related to the root plasma level of Thyroxine and Blood Monocytes Deviation as well as level of Fibroblastes and Eosinophils in Spleen. The listed parameters are almost identical in both vagotonic and sympathicotonic rats (centroids: $+0,43$ and $+0,37$ respectively).

Conclusion. Qualitatively different states of the autonomic nervous system of rats are accompanied by a characteristic constellation of endocrine and immune parameters, one set of which is subordinate to the opposite effects of the sympathetic and vagus link, whereas the other set contains parameters that are not significantly different in sympathicotonic and vagotonic animals and are characteristic of the eutonia.

\section{CONFORMITY TO ETHICAL STANDARDS}

Experiments on animals have been carried out in accordance with the provisions of the Helsinki Declaration of 1975, revised and supplemented in 2002 by the Directives of the National Committees for Ethics in Scientific Research.

The conducting of experiments was approved by the Ethics Committee of the Danylo Halyts'kyi National Medical University. The modern rules for the maintenance and use of laboratory animals complying with the principles of the European Convention for the Protection of Vertebrate Animals used for scientific experiments and needs are observed (Strasbourg, 1985).

\section{Рекомендовано до друку колісією з біоетики}

\section{REFERENCES (ПОСИЛАННЯ)}

1. Baevskiy RM, Kirillov OI, Kletskin SZ. Mathematical Analysis of Changes in Heart Rate by Stress [in Russian]. Moskva: Nauka; 1984: 221 p.

2. Bianco $C$. Population of lymphocytes bearing a membrane receptor for antigen-antibody complex. J Exp Med. 1970; 134(4): 702-20.

3. Bilas VR, Popovych IL. Role of microflora and organic substances of water Naftussya in its modulating influence on neuroendocrine-immune complex and metabolism [in Ukrainian]. Medical Hydrology and Rehabilitation. 2009; 7(1): 68-102.

4. Goryachkovskiy AM. Clinical Biochemistry [in Russian]. Odesa: Astroprint; 1998: 608 p.

5. Hrytsak YL, Barylyak LG, Zukow W, Popovych IL. Cluster analysis of hormonal constellation at women and men with harmonious and disharmonious general adaptation reactions. Journal of Education, Health and Sport. 2016; 6(4): 141-50. 
6. Hrytsak YL, Mysakovets' OG, Mel'nyk OI, Barylyak LG. Features of immunity by various constellations of principal adaptation hormones and autonomous regulation in rats. Experimental and Clinical Physiology and Biochemistry. 2017; 4(80): 13-23.

7. Instructions for application for recruitment reagents for ELISA investigations hormones in the blood of humans [in Russian]. St. Petersburg: JSC «Alkor Bio»; 2000: 21 p.

8. Jondal $M$, Holm G, Wigzell $H$. Surface markers on human T and B lymphocytes. I. A large population of lymphocytes forming nonimmune rosettes with sheep red blood cells. J Exp Med. 1972; 136(2): 207-15.

9. Khaitov RM. Physiology of immune system [in Russian]. Moskva: VINITI RAN; 2005: 428 p.

10. Klecka WR. Discriminant Analysis [trans. from English in Russian] (Seventh Printing, 1986). In: Factor, Discriminant and Cluster Analysis. Moskva: Finansy i Statistika. 1989: 78-138.

11. Kozyavkina $O V$. Post-stress changes in neuroendocrine status and metabolism in rats with different types of initial vegetative homeostasis induced by bioactive water Naftusysa [in Ukrainian]. Medical Hydrology and Rehabilitation. 2009; 7(1): 42-50.

12. Kozyavkina $O V$. State of post-stress parameters of vegetative homeostasis and endocrine, metabolic and immune status as well as the relationship between them in rats with alternative types of precursor vegetative homeostasis induced by bioactive water Naftussya [in Ukrainian]. Medical Hydrology and Rehabilitation. 2009; 7(2): 40-56.

13. Kozyavkina $O V$. Vegetotropic effects of bioactive water Naftussya in male rats and their endocrine, electrolyte and immune accompaniments [in Ukrainian]. Medical Hydrology and Rehabilitation. 2012; 10(3): 65-92.

14. Kozyavkina $O V$, Barylyak LG. Ambivalent vegetotropic effects of bioactive water Naftussya and opportunity of their forecasting at rats. Medical Hydrology and Rehabilitation. 2008; 6(3): $123-7$.

15. Kozyavkina OV, Kozyavkina NV, Gozhenko OA, Gozhenko AI, Barylyak LG, Popovych IL. Bioactive Water Naftussya and Neuro-Endocrine-Immune Complex [in Ukrainian]. Kyiv: UNESCO-SOCIO. 2015. 349 p.

16. Lapovets' LYe, Lutsyk BD. Handbook of Laboratory Immunology [in Ukrainian]. Lviv; 2002: 173 p.

17. Limatibul S, Shore A, Dosch HM, Gelfand EW. Theophylline modulation of E-rosette formation: an indicator of T-cell maturation. Clin Exp Immunol. 1978; 33(3): 503-513.

18. Popovych IL. Functional interactions between neuroendocrine-immune complex in males rats [in Ukrainian]. Achievements of Clinical and Experimental Medicine. 2008; 2(9): 80-87.

19. Popovych IL. Influence of the course on the use of bioactive water Naftussya on vegetative regulation in rats in basal and post-stress periods [in Ukrainian]. Medical Hydrology and Rehabilitation. 2008; 6(2): 79-83.

20. Popovych IL. The concept of neuroendocrine-immune complex (Review) [in Russian]. Medical Hydrology and Rehabilitation. 2009; 7(3): 9-18.

21. Popovych $I L$. The factor and canonical analysis parameters of neuro-endocrine-immune complex, metabolism and erosive-ulcerose injuries of mucous stomach at rats in conditions of acute water immersing stress [in Ukrainian]. Medical Hydrology and Rehabilitation. 2007; 5(2): 68-80.

22. Popovych IL, Polovynko IS, Zajats LM, Mel'nyk OI. Sexual dimorphism of the neuroendocrine-immune complex and its reactions on chronic stress at rats. Experimental and Clinical Physiology and Biochemistry. 2018; 3(83): 5-17.

23. Popovych IL, Struk ZD, Vis'tak-Markevych HI, Duda NB, Korda MM. Sexual dimorphism of reactions of the neuroendocrine-immune complex and metabolism to adaptogenic balneotherapy in individuals with dysadaptosis. In: Proceedings XI Scientific Conference "Issues of pathology in conditions of extreme factors action on the body» (Ternopil', 4-5 October 2018). Ternopil'. 2018: 49-50.

24. Popovych IL, Vis'tak HI, Gumega MD, Ruzhylo SV. Vegetotropic Effects of Bioactive Water Naftussya and their Endocrine-Immune, Metabolic and Hemodynamic Accompaniments [in Ukrainian]. Kyiv: UNESCO-SOCIO; 2014: 163 p.

25. Sydoruk NO, Gozhenko AI, Zukow W. Modulating effects of bioactive water Naftussya from layers Truskavets' and Pomyarky on neuro-endocrine-immune complex and metabolism at rats exposed to acute stress. Journal of Education, Health and Sport. 2016; 6(11): 715-30.

26. Vis'tak HI, Popovych IL. Vegetotropic effects of bioactive water Naftussya and their endocrine and immune support in female rats [in Ukrainian]. Medical Hydrology and Rehabilitation. 2011; 9(2): 39-57. 


\title{
RESEARCH ARTICLE
}

\section{Features of Endocrine and Immune Status in Rats with Different State of Autonomous Nervous System}

\author{
O.I. MELNYK', O.G. MYSAKOVETS ${ }^{1}$, I.L. POPOVYCH ${ }^{2,3}$ \\ ${ }^{1}$ Danylo Halytskyi National Medical University, Lviv, Ukraine \\ ${ }^{2}$ OO Bohomolets Institute of Physiology, Kyiv, Ukraine \\ ${ }^{3}$ Ukrainian Scientific Research Institute of Medicine for Transport, Odesa, Ukraine

\section{E-mail:oksana@meduniv.lviv.ua; i.popovych@biph.kiev.ua}

The presence of interconnections between the parameters of the nervous, endocrine and immune systems within the framework of the triple complex is well known. However, data on the nature (synergism or antagonism) of the influence of the sympathetic and vagus link of the autonomic nervous system on the individual parameters of immunity are ambiguous. One of the approaches to solving this problem is to compare immunity parameters in individuals with different states of the autonomic nervous system. This is what determined the purpose of this study.

The experiment is at 60 female and 50 male white rats Wistar line weighing 210-320 g. Of these for 10 animals of each sex not subjected to any influences and others within 6-7 days were subjected to different stressing or adaptogenic manipulations. The day after the completion of manipulations in all rats determined parameters of heart rate variability and leukocytogram. The next day, the animals were decapitated, for the purpose of collecting blood. The plasma levels of the hormones of adaptation were determined: corticosterone, triiodothyronine, thyroxine and testosterone; as well as electrolytes: calcium, phosphates, sodium and potassium for evaluation parathyrin, calcitonin and mineralocorticoid activities. On the state of the phagocytic function of microphages and macrophages judged by phagocytic index, microbial number and index of killing regarding museum culture Staphylococcus aureus. Among the parameters of immunogram determined the relative amount of blood population of T-cells, their theophylline resistant and sensitive subpopulations as well as the population of B-lymphocytes and Natural killers. From the spleen and thymus did smears for counting splenocytogram and thymocytogram. For the latter, as well as immunocytogram and leukocytogram we calculated entropy.

Three groups were formed according to the integral state of the autonomic nervous system evaluated by Baevskiy Stress-index. The eutonia was confirmed in 25 rats (14 males and 11 females). In 33 rats (12 males and 21 females) vagotonia was confirmed, whereas in 52 rats (24 males and 28 females) sympathicotonia was observed. Discriminant analysis detected 17 parameters, the totality of which three states of autonomous regulation differ significantly. In particular, in addition to the three HRV parameters, by definition, three endocrine parameters, two parameters of thymocytogram, five parameters of splenocytogram and three immune parameters of blood appeared to be characteristic.

Qualitatively different states of the autonomic nervous system of rats are accompanied by a characteristic constellation of endocrine and immune parameters, one set of which is subordinate to the opposite effects of the sympathetic and vagus link, whereas the other set contains parameters that are not significantly different in sympathicotonic and vagotonic animals and are characteristic of the eutonia.

Key words: heart rate variability, corticosterone, triiodothyronine, thyroxine, testosterone, phagocytosis, cellular and humoral immunity, female and male rats. 